D. H. LAWRENCE AND THE AUTHORITARIAN PERSONALITY 


\title{
D. H. Lawrence and the Authoritarian Personality
}

\author{
Barabara Mensch \\ Department of English \\ Concordia College, Edmonton, Alberta
}

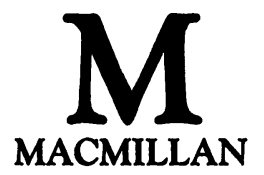


(c) Barbara Mensch 1991

Softcover reprint of the hardcover 1st edition 1991 978-0-333-55543-9

All rights reserved. No reproduction, copy or transmission of this publication may be made without written permission.

No paragraph of this publication may be reproduced, copied or transmitted save with written permission or in accordance with the provisions of the Copyright, Designs and Patents Act 1988 or under the terms of any licence permitting limited copying issued by the Copyright Licensing Agency, 33-4 Alfred Place, London WC1E 7DP.

Any person who does any unauthorised act in relation to this publication may be liable to criminal prosecution and civil claims for damages.

First published 1991

Published by

MACMILLAN ACADEMIC AND PROFESSIONAL LTD

Houndmills, Basingstoke, Hampshire RG21 2XS

and London

Companies and representatives

throughout the world

British Library Cataloguing in Publication Data

Mensch, Barbara

D. H. Lawrence and the authoritarian personality.

1. Fiction in English. Lawrence, D. H. (David Herbert)

1885-1930

I. Title

823.912

ISBN 978-1-349-12457-2

ISBN 978-1-349-12455-8 (eBook)

DOI 10.1007/978-1-349-12455-8 
For my husband and my son

Fred and Julian 


\section{Acknowledgments}

Thanks and acknowledgement are due to Henry Holt and Company, Inc. for permission to quote, in the United States edition of this book, from The Three Faces of Fascism: Action Française, Italian Fascism, National Socialism by Ernst Noltë. Copyright (c) 1963 by R. Piper and Co. Verlag. Translated by Leila Vennewitz. Translation (C) 1965 by R. Piper and Co. Verlag. Reprinted by permission of Henry Holt and Company, Inc.; for the U.K. rights to quote from this publication I thank George Weidenfeld and Nicolson Ltd. Thanks are also due to the University of California Press for permission to quote from Fritz Stern, Politics of Cultural Despair: A Study in the Rise of the Germanic Ideology. Copyright (C) 1961, The Regents of the University of California. Finally, I gratefully acknowledge permission from Harper \& Row to quote from the definitive study by T.W. Adorno, et al., The Authoritarian Personality, Harper \& Row, 1950.

A warm thanks to the following individuals, all of whom had considerable input with regard to the direction and form that this book, which was originally my doctoral dissertation, has taken: Fred Radford, Chris Bullock, Nora Stovel, Gary Watson, George Zytaruk and Jerald Zaslove.

Thanks also to Kermit Hummel for taking on the project, and to Simon Winder for his enthusiastic and encouraging support.

Finally, a very warm note of love and thanks to my husband Fred, for all the typing, grammar checks, editorial and production work which he has put into the project. 


\section{Contents}

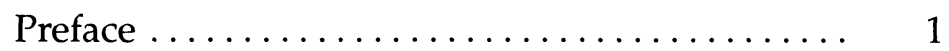

1 Lawrence, Authoritarianism and Fascism:

The Critical Response ................... 7

2 The Problems of Definition ............... 23

3 "The Pathology of Cultural Criticism" ....... 55

4 Authoritarian, Totalitarian and Utopian

Elements in Women in Love ............... 71

5 The Search for a Leader in Aaron's Rod ...... 119

6 Leaders and Followers in Kangaroo .......... 171

7 Fascism and Authoritarianism in

The Plumed Serpent.................... 207

Conclusion $\ldots . \ldots \ldots \ldots \ldots \ldots \ldots \ldots \ldots . \ldots 253$

Works Cited $\ldots \ldots \ldots \ldots \ldots \ldots \ldots \ldots \ldots \ldots, 263$

Index $\ldots \ldots \ldots \ldots \ldots \ldots \ldots \ldots \ldots \ldots \ldots \ldots \ldots \ldots, 271$ 
He ran out, blindly, as if from the dark, probably thinking that now he was free. Then he stopped short, seeing he was not free, but surrounded in an unknown way.

The Plumed Serpent 


\section{Preface}

Almost sixty years after Lawrence's death, some of the major themes dominating his work still seem unreconcilable. How could this poet of consumate spontaneity, tenderness and sexual freedom also endorse charismatic leaders and obedient followers, as well as authoritarian personality elements that have led to accusations of "fascism" in his work? Bertrand Russell is one of Lawrence's strongest detractors in this area, claiming that Lawrence's theory of blood consciousness "led straight to Auschwitz" (115). The rigid authoritarian attitude that emerges in some of Lawrence's work seems totally at odds with the spontaneity of perception, and the complexity of character that dominates most of his writing. The incongruity of these elements in Lawrence's work has never been satisfactorily analyzed.

There is also considerable ambiguity surrounding the term "fascism" and how it relates to authoritarianism. Fascism might be defined as the political externalization of authoritarian personality elements; there are, of course, different kinds of fascism, though the tendency is to identify the term strictly with German National Socialism. Hannah Arendt distinguishes between fascism and totalitarianism; whatever the distinctions, and these will be 
examined later, at bottom of any fascist or totalitarian platform are the psychological forces of the authoritarian.

Lawrence's work shows very clearly that he recognized the authoritarian personality and incorporated it into his writing; this recognition, however, does not constitute an endorsement of the rigid personality that would be receptive to the negative, life-denying political structures of fascism and totalitarianism. Wherever Lawrence draws an authoritarian personality type, he counters it with another personality that is honest, feeling, and what might even be defined, in the fullest sense of the word, as "liberal."

Fascism is a difficult concept to deal with, even in the 1980s; it is doubly difficult to ascertain correctly what was understood as fascism within Lawrence's time. Those early years of fascist development, and of political affiliations in general, were a time of extreme confusion. As evidence of the political instability of the period, Winston Churchill, elected to Parliament as a Conservative, crossed the floor in 1900 to join the Liberals instead (he was accused of "socialist" leanings for this move). England, like other European countries, had coteries of socialist movements since the late nineteenth century, and the real fear in the English "establishment" of this time was not of authoritarianism, but of socialism. King George V "thought of any individual or movement tinged with 'socialism' as inimicable to the throne," and thought that Churchill's views were "very socialistic" (Jenkins 235).

This concern with socialism, rather than with rightwing authoritarian politics, was reinforced by conservatives throughout Europe after the 1917 Russian revolution, with its attack on the aristocracy and established order. Mussolini's "fascism," on the other hand, attracted amused, 
but rarely fearful notice, as Lawrence himself notes as late as 1928:

Why, having come out from England to find mountains, lakes, scythe-mowers and cherry trees, does the little blue-eyed lady resolutely close her blue eyes to them all, now she's got them, and gaze away to Signor Mussolini, whom she hasn't got, and to Fascism, which is invisible anyhow? (Phoenix II 533)

There was very little negative reaction to fascism during Lawrence's lifetime because few people viewed it as the regressive tyranny it turned out to be; there is little evidence of any active protest against the dangers of an authoritarian order until the time of the Spanish Civil War. By then, the protesters were a curious blend of ardent socialists, people like Nancy Cunard, the model for Lucy Tantamount in Aldous Huxley's Point Counter Point, who worked as a war correspondent in the Spanish civil war (Fielding 121). Many writers of the twenties were apathetic - or contemptuous - toward existing political systems. Virginia Woolf is a good case in point; her view of politicians is expressed in the comment: "...what humbugs they all are! - or rather hypnotised by the incantation of some siren quite invisible to the outside world..." (Letters 283). Lawrence's battles with political criticism centered primarily around the censoring of erotica in his works; no critic found fascist themes in The Plumed Serpent at that time. It was not until three years after Lawrence's death that T.S. Eliot wrote:

A man like Lawrence ... with his acute sensibility, violent prejudices and passions, and lack of intellectual and social training, is admirably fitted to be an instrument for forces of good or for forces of evil; 
or as we might expect, partly for one and partly for the other. A trained mind like that of Mr. Joyce is always aware what master it is serving; an untrained mind, and a soul destitute of humility and filled with self-righteousness, is a blind servant and a fatal leader. (After Strange Gods 58-59)

Eliot accuses Lawrence of promoting the forces of evil through his art, but Eliot would not necessarily have argued that authoritarian systems are evil. In the same lectures he emphasizes that "the struggle of our time [is] to concentrate, not to dissipate; to renew our association with traditional wisdom; to re-establish a vital connexion between the individual and the race; the struggle in a word, against Liberalism" (48-49). Eliot's belief in a renewed classicism is really another approach to an authoritarian order. As Peter Ackroyd notes, Eliot, by his twenties, had identified himself with an intellectual movement, "the main tenets of which were an attack upon humanitarianism and liberal democracy, the espousal of a hard classicism after the flatulence of Rousseauist 'self-expression,' the affirmation of absolute and objective values, and the recognition of the need for order and authority to discipline man's fallen state" (76). If Eliot disapproves of Lawrencian art, it is because he feels that Lawrence lacks any "moral or social sense" (Ackroyd 36-37), not because of a specific political philosophy that Lawrence endorses.

There exists, then, a need to distinguish clearly between authoritarianism, totalitarianism and fascism. With these definitions established, they may be applied to the actions and behavior of specific characters in Lawrence's novels, to determine whether or not these characters display authoritarian attributes. In Women in Love, Gerald Crich is an authoritarian personality; the novel ends, however, 
with Birkin's unfulfilled desire for an intimate community of people that extends beyond the marriage bond. ${ }^{1}$ After Women in Love, Lawrence moves toward a further examination of communal relationships and the need for a leader. Aaron's Rod may be seen as Lawrence's attempt to be a leader, Kangaroo as his trial at being a follower, and finally, The Plumed Serpent as a futuristic attempt on his part to imagine the perfect relationship between leader and follower.

${ }^{1}$ Lawrence also expresses this desire outside the fictional world in his ideal of Rananim, as expressed most clearly in a letter of January 1915 to Koteliansky, in The Quest for Rananim. (Zytaruk 22) 